\title{
Knowledge of women receiving healthcare services on the tasks of midwife working in the primary health care
}

\author{
Wiedza kobiet korzystających ze świadczeń zdrowotnych na temat zadań położnej pracującej \\ w podstawowej opiece zdrowotnej
}

\section{Joanna Piechowska' , Grażyna Iwanowicz-Palus², Agnieszka Bień2 , Agnieszka Pieczykolan}

\author{
'doktorantka Wydziału Nauk o Zdrowiu, Uniwersytet Medyczny w Lublinie \\ /PhD student at the Faculty of Health Sciences, Medical University of Lublin \\ 2Zakład Podstaw Położnictwa, Wydział Nauk o Zdrowiu, Uniwersytet Medyczny w Lublinie \\ /Department of the Basics of Midwifery, Faculty of Health Sciences, Medical University of Lublin
}

AUTOR DO KORESPONDENCJI/CORRESPONDING AUTHOR: Joanna Piechowska e-mail: j.piechowska91@gmail.com ul. Staszica 4/6, 20-081 Lublin

\section{STRESZCZENIE}

Słowa kluczowe:

ABSTRACT

\section{WIEDZA KOBIET KORZYSTA JĄCYCH ZE ŚWIADCZEN ZDROWOTNYCH NA TEMAT ZADAŃ POLOŻNEJ PRACUJĄCEJ W PODSTAWOWEJ OPIECE ZLROWOTNEJ}

Cel pracy. Celem pracy była próba określenia stanu wiedzy kobiet korzystających ze świadczeń zdrowotnych na temat zadań położnej w systemie podstawowej opieki zdrowotnej.

Materiał i metodyka. Badania zostały przeprowadzone online w okresie od lutego do marca 2018 roku wśród kobiet korzystających ze świadczeń zdrowotnych w podstawowej opiece zdrowotnej. W badaniu wzięło udział 200 respondentek w wieku 18-60 lat, które zostały poinformowane o dobrowolności, anonimowości udziału w badaniach i wykorzystaniu wyników wyłącznie do celów naukowych. Do badań wykorzystano metodę sondażu diagnostycznego z wykorzystaniem autorskiego kwestionariusza ankiety.

Wyniki. Większość ankietowanych znała swojego lekarza podstawowej opieki zdrowotnej (87,5\%), a jedynie połowa respondentek znała swoją położną (50\%). Położna była kojarzona przede wszystkim ze świadczeniami dotyczącymi porodu oraz opieki nad noworodkiem. W świadomości kobiet położna może prowadzić edukację (72\%), jednak w większości były przekonane o możliwości poradnictwa w zakresie ciąży, połogu, wczesnego macierzyństwa.

Wnioski. 1. Kobiety korzystające ze świadczeń zdrowotnych mają niepełną wiedzę na temat tego, kto jest ich lekarzem, położną i pielęgniarką w podstawowej opiece zdrowotnej. 2. W świadomości kobiet istnieje przekonanie, że położne (w tym położne podstawowej opieki zdrowotnej) zajmują się wyłącznie kobietami w ciąży i po porodzie, natomiast nie wiedzą, iż położne zajmują się także edukacją dotyczącą profilaktyki chorób ginekologicznych. 3. W nawiązaniu do niskiego poziomu wiedzy społeczeństwa na temat kompetencji położnej podstawowej opieki zdrowotnej konieczne jest prowadzenie działań mających na celu promowanie zawodu położnej i uświadamianie społeczeństwa w tym zakresie.

położna, zawód, podstawowa opieka zdrowotna

Aim. The aim of the study was to determine the state of knowledge of women using health services on the midwife's tasks in the primary health care.

Material and methods. The research was conducted online in the period from February to March 2018 among women receiving health services in primary health care. The study was attended by 200 respondents aged 18-60 - they were informed about the voluntariness, anonymity of participation in research and the use of results only for scientific purposes. The diagnostic survey method was used for the research using the author's questionnaire.

Results. Most of the respondents knew their family physician (87.5\%) and only half of the respondents knew their midwife (50\%). The midwife was mainly associated with childbirth and neonatal care. In the minds of women, the midwife can conduct education (72\%), but most of them only knew about the possibility of counseling in the field of pregnancy, postpartum period, early motherhood. Conclusions. 1. Women receiving healthcare services have incomplete knowledge of who their physician, midwife and nurse are in primary health care. 2. In the consciousness of women, there is the idea that midwives (including midwives of primary health care) deal only with pregnant women and after childbirth, but they do not know that midwives are involved in education regarding the prevention of gynecological diseases. 3. In reference to the low level of public knowledge about primary health care midwife's competence, it is necessary to conduct activities aimed at promoting the midwife profession and raising public awareness in this area. 


\section{INTRODUCTION}

The profession of midwife has been existing for hundreds years and is related to every social class regardless of origin, age or epoch. Generally, midwife was assisting a woman during labor, she was advising her during the first days of baby's life as well as she was sharing her knowledge on natural methods related to private part ailment. Accoucheuses, as they were used to called, were supporting women in many moments of their life, what still functions in hospital, ambulatory and home environments. Midwife is considered by society as a needed and useful person since actions performed by her correlate with human needs $[1,2]$.

Midwife position was determined in the Law of 15 July 2011 on the professions of nurse and midwife, where she was recognized as a person providing health services after obtaining essential qualifications [3]. Currently, midwife can perform various functions in health care system, including being a part of primary health care workgroup (Polish POZ) along with doctor and nurse $[3,4,5]$.

According to the Law of 27 October 2017 on elementary health care, primary health care midwife (in other words family midwife) is a midwife that works in medical facility with a signed contract with National Health Fund (Polish NFZ) on providing medical/health services or that signed it on her own and that meets one of the following criteria: has got a professional title of master of midwifery; has got a title of specialist or is doing a qualification course in the field of family nursery; has got a title of specialist in the field of nursery: community nursery, community-family nursery as well as promotion of health and health education or has completed a qualification course in the field of nursery: community nursery, community-family nursery as well as promotion of health and health education $[4,6]$.

Patients having health insurance in Poland, that is recipients, are entitled to choose specific members of primary health care workgroup - doctor, nurse and midwife (for boys up to 2 months old and for women from birth to old age). Such a choice is being taken by means of so called "declaration of choice", namely by means of statement of intent given in a written form in a selected medical facility $[4,6]$.

Women in Poland are entitled to benefit from a number of health services that can be performed by midwife, including family midwife. Among society, she is mainly identified with delivering a baby and midwife home visits (after labor), rarely with actions that are not connected to pregnancy. However, the range of medical actions provided by midwives is significantly wider [1].

According to law that is in force in Poland, midwife has got a right to take care of a woman with physiological pregnancy or interpret her results [3]. Similar legal rules have been determined in other European countries, such as England and France [8]. Nonetheless, in case of exclusive care over pregnant woman by midwife, she has to refer woman for a consultation to a specialty doctor (in the field of midwifery and gynecology) three times during pregnancy as well as for ultrasonography examination according to current standard of medical procedure. Moreover, woman should be referred to midwife by her doctor between 21 and 26 week of pregnancy [3]. Primary health care midwife, apart from diagnosing and keeping the course of physiological pregnancy, also nurses the baby from the first seconds of its life, does breastfeeding counseling for young mothers and evaluates normal development of newborn baby. She gives professional advice on family planning, pregnancy course (e.g. diet, physical activity, means of alleviating ailments related to pregnancy) and on labor (such as labor positions, means of relaxation), on prevention of female tumor diseases or sexually transmitted diseases (e.g. HIV) [3]. These services are financed by National Health Fund and respectively calculated based on performed service [6].

\section{AIM}

The aim of the study was to determine the state of knowledge of women receiving health services on the midwife's tasks in the primary health care.

\section{MATERIALS AND METHODS}

Research has been conducted online within the period from February till March 2018 among women living in Poland who benefit from health services of primary health care. As many as 200 respondents at age of 18-60 took part in the research. They were informed about voluntary and anonymous part in the research as well as about the fact that results would be only used for scientific purposes. For research, diagnostic survey method has been applied, with help of authorial survey questionnaire that was compiled on the basis of literature of subject.

Received results were subject to statistical analysis. Data base and statistical research were conducted based on computer software STATISCTICA 13.3 (StatSoft, Poland). Values of analyzed immeasurable parameters were presented by means of quantity and percent. For unrelated qualitative characteristics, homogeneity test $\mathrm{Chi}^{2}$ was applied in order to detect differences between the compared groups. Materiality level was set to $\mathrm{p}<0.05$.

\section{RESULTS}

Most of the surveyed women lived in the city (80.0\%), received higher education $(77.0 \%)$, over half of them were married (52.5\%) and had children (52.5\%).

Among respondents, most women benefited from primary health care services (95.50\%), namely: $72.5 \%$ a few times per year, $11.0 \%$ once per month, $2.0 \%$ more than once per month, whereas $14.5 \%$ did not benefit from such services last year (see Figure 1).

Conducted analysis indicates that more frequently respondents knew their primary health care doctor $(87.5 \%)$ than their primary health care nurse and midwife $(\mathrm{p}=0.05)$ (see Table 1$)$. 


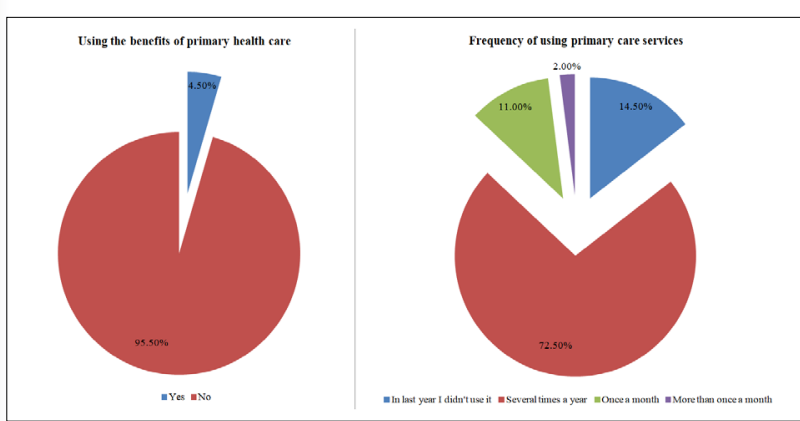

Fig 1. The use of primary care services by respondents

Tab. 1. Knowledge of individual members of primary health care team

\begin{tabular}{|c|c|c|c|c|c|c|c|}
\hline \multirow{2}{*}{$\begin{array}{l}\text { Knowledge of } \\
\text { primary health } \\
\text { care team }\end{array}$} & \multicolumn{2}{|c|}{$\begin{array}{c}\text { Family } \\
\text { physician }\end{array}$} & \multicolumn{2}{|c|}{$\begin{array}{l}\text { Family } \\
\text { nurse }\end{array}$} & \multicolumn{2}{|c|}{$\begin{array}{c}\text { Family } \\
\text { midwife }\end{array}$} & \multirow{2}{*}{$\begin{array}{c}\text { Statistical } \\
\text { analysis }\end{array}$} \\
\hline & $\mathbf{N}$ & $\%$ & $\mathbf{N}$ & $\%$ & $\mathbf{N}$ & $\%$ & \\
\hline Yes & 175 & 87.5 & 82 & 41.0 & 100 & 50.00 & \multirow{3}{*}{$\begin{aligned} \mathrm{Chi}^{2} & =0.00075 \\
\mathrm{p} & =0.05\end{aligned}$} \\
\hline No & 15 & 7.5 & 86 & 43.0 & 66 & 33.00 & \\
\hline $\begin{array}{l}\text { I don't know, } \\
\text { if I have it }\end{array}$ & 10 & 5.0 & 32 & 16.0 & 34 & 17.00 & \\
\hline
\end{tabular}

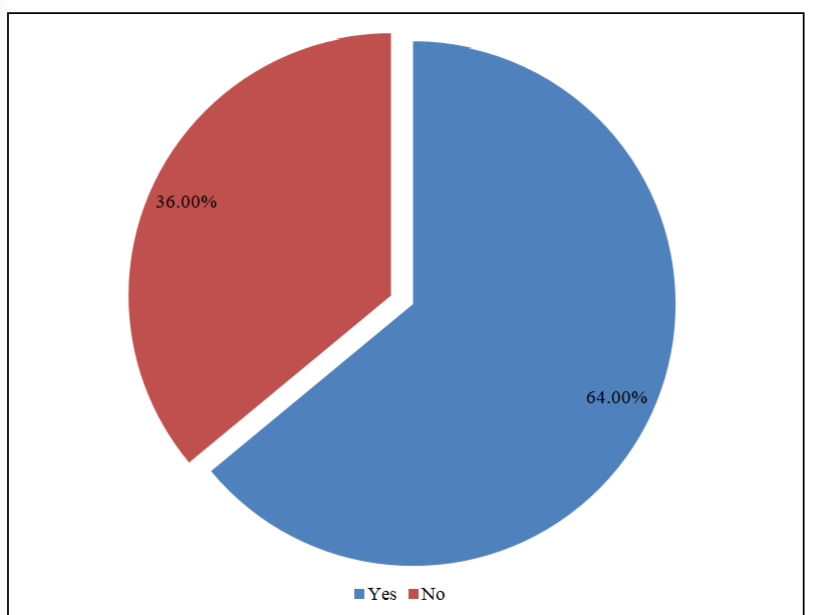

Fig 2. The knowledge of respondents about having a declared midwife POZ

A significant number of respondents confirmed that every woman should have a declared midwife from primary health care (64.0\%) (see Figure 2).

The majority of respondents indicated that midwife takes care of woman after giving birth (88.0\%) and of newborn baby ( $84.0 \%)$, is able to keep the course of physiological pregnancy $(71.0 \%)$ and educates on prevention of female diseases (63.0\%) (see Table 2).

According to standard practice, family midwife does at least 4 home visits for a woman after labor. Among 51.43\% respondents, midwives conducted the required number of visits - namely $29.52 \%$ got 4 to 5 visits and $21.90 \%$ got 6 home visits or more. Unfortunately, $44.76 \%$ of respondents got less home visits or there were no home visits at all (23.81\%) (see Figure 3).

Over half of the surveyed women responded that primary health care midwife takes care of women (from birth to old age) and of boys up to 2 months old (58.5\%). However, almost one third of respondents believed that midwife only takes care of woman during pregnancy and after labor (29.0\%) and few think that she takes care of only children up to 2 months old (4.5\%). Moreover, $8.0 \%$ of respondents did not know at all their midwife (see Figure 4).
Tab. 2. Knowledge of the respondents on family midwife's tasks

\begin{tabular}{|l|c|c|}
\hline \multicolumn{1}{|c|}{ Midwife's tasks in primary health care } & N & $\%$ \\
\hline Caring for women after childbirth & 176 & 88.0 \\
\hline $\begin{array}{l}\text { Caring for newborn after return from hospital until 2. months } \\
\text { old }\end{array}$ & 168 & 84.0 \\
\hline $\begin{array}{l}\text { Caring for women at physiological pregnancy } \\
\text { (without complications) from conception to labor }\end{array}$ & 142 & 71.0 \\
\hline Educating about prevention of women's diseases & 126 & 63.0 \\
\hline Caring for women after gynecological surgery / treatments & 112 & 56.0 \\
\hline $\begin{array}{l}\text { Giving medications by different ways and techniques } \\
\text { (as directed by physician) }\end{array}$ & 95 & 47.5 \\
\hline $\begin{array}{l}\text { Providing first aid in life-threathing situations } \\
\text { or in case of sudden birth (including endangered birth) }\end{array}$ & 95 & 47.5 \\
\hline Assisting in exams taking by physician & 92 & 46.0 \\
\hline $\begin{array}{l}\text { Printing prescription for drugs and medicine devices } \\
\text { (with some exceptions) }\end{array}$ & 67 & 33.5 \\
\hline I don't know & 7 & 3.50 \\
\hline
\end{tabular}

${ }^{*}$ results do not add up to $100 \%$, because it was possible to mark several answers

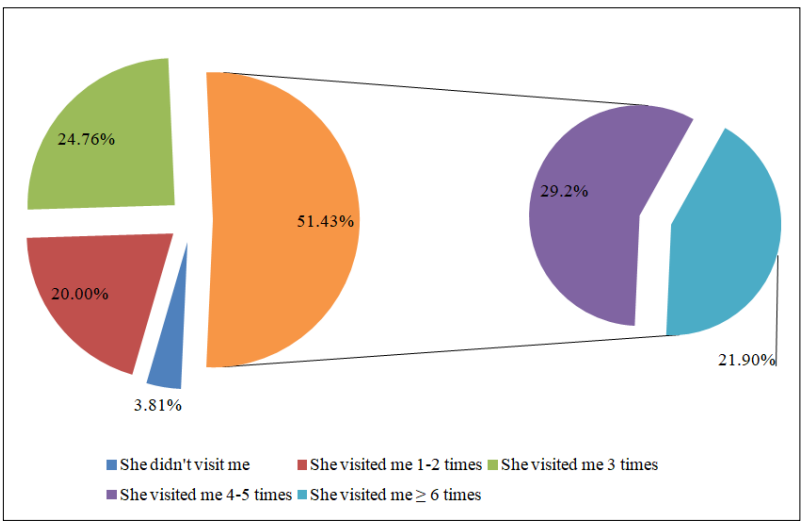

Fig 3. Number of patronage visits made by a midwife of primary health care according to the respondents who gave birth to the child



- Fig 4. Group of patients who are taken care of by a midwife of primary health care according to respondents 
To question related to the possibility of appointing an educational visit with family midwife, over two third of respondents unanimously claimed that every woman has got such a possibility $(72.0 \%)$, whereas every fifth respondent did not know the answer to that question (20.5\%) (see Figure 5).

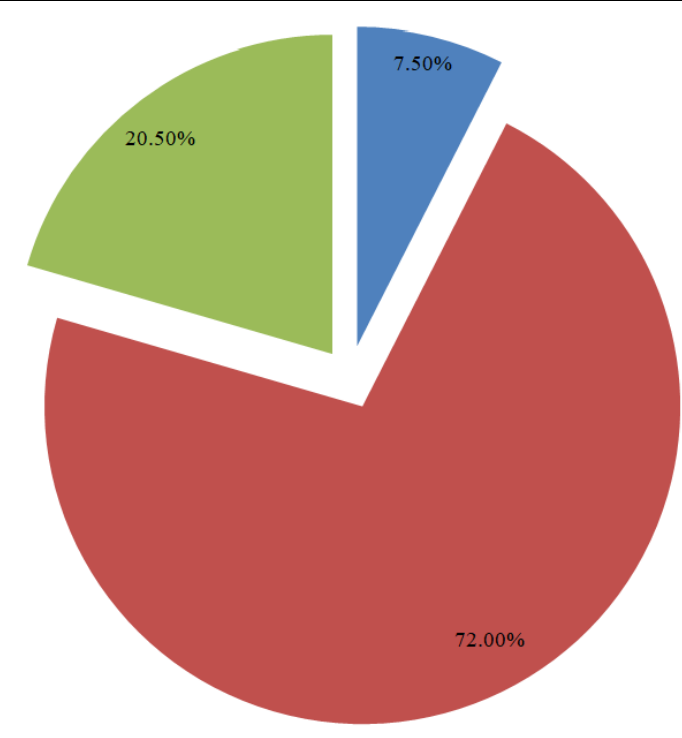

EYes, but only for pregnancy women $\quad$ EYes, for all women $\quad$ I don't know

Fig 5. Opinion of the respondents on the possibility of arranging for educational advice to a midwife

The surveyed women, to question related to the range of educational advice given by primary health care midwife, usually responded that its topics are related to preparation for labor, including family labor $(92.0 \%)$, nursing and feeding of baby up to 2 months old (84.0\%), breastfeeding counseling and breastfeeding promotion (83.5\%) (see Table 3).

Tab. 3. Women's knowledge about aspects of educational advice carried by midwife in primary health care

\begin{tabular}{|l|c|c|}
\hline \multicolumn{1}{|c|}{ Aspects of educational advice by family midwife } & N & \% \\
\hline Preparing to labor, including family birth & 184 & 92.00 \\
\hline Nursing and proper nutrition of baby until two months old & 168 & 84.00 \\
\hline Lactation counseling and promotion of breast feeding & 167 & 83.50 \\
\hline $\begin{array}{l}\text { Prevention of gynecological diseases and obstetrical } \\
\text { pathology }\end{array}$ & 134 & 67.00 \\
\hline $\begin{array}{l}\text { Taking self-observation and taking action in order to early } \\
\text { detection and elimination cancer risk factors }\end{array}$ & 133 & 66.50 \\
\hline $\begin{array}{l}\text { Returning fertility after birth and methods of fertility } \\
\text { regulation }\end{array}$ & 126 & 63.00 \\
\hline Education about protective vaccinations at babies & 122 & 61.00 \\
\hline Shaping parental attitudes & 114 & 57.00 \\
\hline Prevention of developmental age diseases & 99 & 49.50 \\
\hline Prevention of HIV infections and sexual transmitted diseases & 111 & 55.50 \\
\hline
\end{tabular}

* results do not add up to $100 \%$, because it was possible to mark several answers
Conducted survey indicates that according to respondents, primary health care midwife mainly monitors postpartum period, development of newborn and infant up to 2 months old (86\%) and takes measurements of woman and newborn and evaluates outcomes $(82.0 \%)$, whereas less frequently she provides referrals for specific diagnostic examinations (44.5\%) (see Table 4).

Tab. 4. Women's knowledge about services provided by midwife in primary health care

\begin{tabular}{|l|c|c|}
\hline \multicolumn{1}{|c|}{ Providing medical services by midwife } & N & $\%$ \\
\hline $\begin{array}{l}\text { Monitoring progress of post-partum period and development } \\
\text { of newborn and infant until two months old }\end{array}$ & 172 & 86.00 \\
\hline $\begin{array}{l}\text { Taking measurement at woman and newborn and making } \\
\text { evaluate those measurements }\end{array}$ & 164 & 82.00 \\
\hline $\begin{array}{l}\text { Leading breathing, relaxation and preparing to labor } \\
\text { and post-partum period gymnastics }\end{array}$ & 153 & 76.50 \\
\hline Taking sudden labor at home conditions & 146 & 73.00 \\
\hline $\begin{array}{l}\text { Leading improving exercise in pregnancy, } \\
\text { post-partum period and gynecological diseases }\end{array}$ & 144 & 72.00 \\
\hline $\begin{array}{l}\text { Leading and monitoring development of physiological } \\
\text { pregnancy }\end{array}$ & 134 & 67.00 \\
\hline Collection materials to diagnostic tests & 126 & 63.00 \\
\hline Performing obstetric / gynecological examination at women & 123 & 61.50 \\
\hline Printing referrals for specific diagnostic tests & 89 & 44.50 \\
\hline
\end{tabular}

*results do not add up to $100 \%$, because it was possible to mark several answers

Most of the surveyed women responded that medical services provided by primary health care midwives are free of charge $(69.5 \%)$, whereas the rest of respondents claimed that these services are chargeable (3.5\%) or did not have any opinion on it (27.0\%) (see Figure 6).

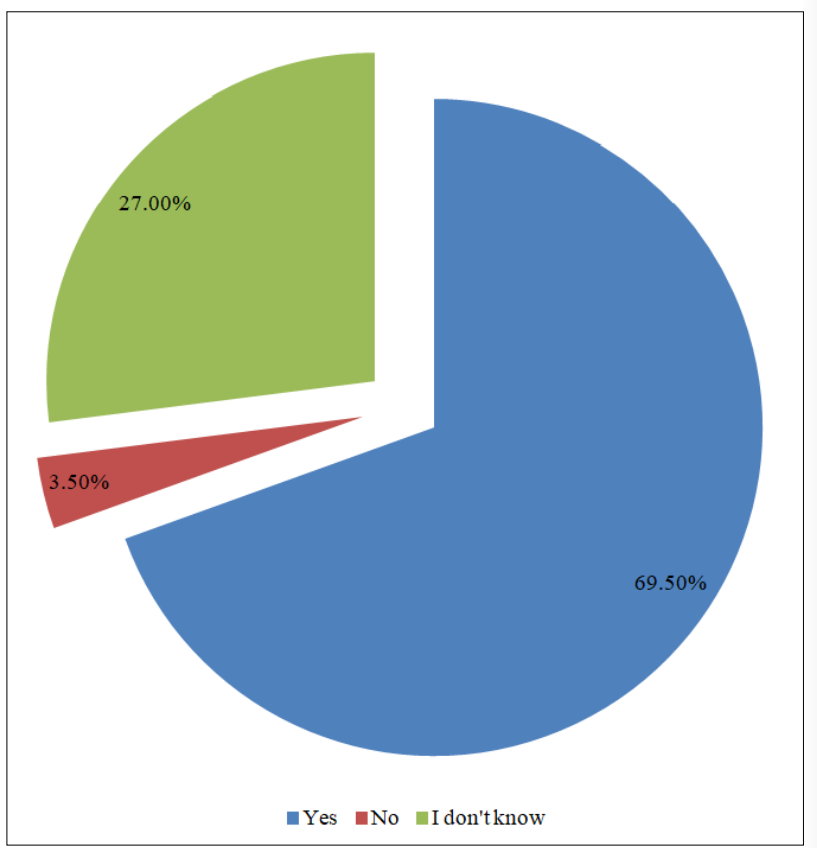

Fig 6. The knowledge of the respondents on the payment for services provided by a midwife of primary health care 
To question related to the meaning of the position of family midwife over half of respondents said that midwife is an indispensable person in primary health care workgroup $(79.5 \%)$, whereas the rest of women did not have any opinion on it $(15.0 \%)$ or believed that midwife is not an obligatory member of primary health care workgroup (5.5\%) (see Figure 7).

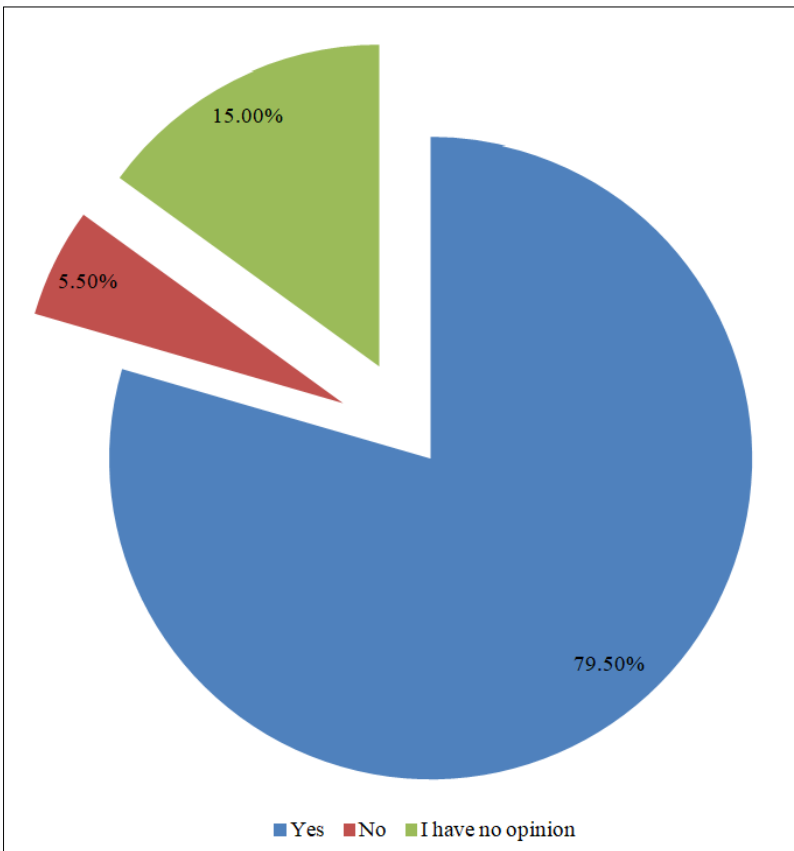

Fig 7. Respondents' opinion on the importance of a midwife in the primary health care team

\section{DISCUSSION}

Thanks to legal conditions that apply in Poland, a midwife has got a wide range of professional competences. Acquired knowledge and abilities enable her to provide various medical services on her own in hospital and ambulatory environment [3].

During the period of conducting this research, essential information has been gathered on knowledge of women who benefit from health services that pertain to medical services provided by primary health care midwives. According to the opinion of respondents, family midwife can take care of woman in physiological pregnancy (67\%) and monitor postpartum period (86\%). This is also confirmed in works of some authors who relate to legal acts enabling midwives to take care of women in this period, however, research from 2015-2016 indicated that over half of respondents (61\%) did not know that midwife may be the person to keep the course of pregnancy $[1,9]$.

Research results indicate that according to respondents, the main group of recipients of services provided by family midwives were women in postpartum period and newborns up to 2 months old, what was also shown in research from 1999 and 2011. However, every analysis, according to the opinion of respondents, shows that to a lesser extent midwife takes care of patients after gynecological surgery and gives advice related to developing parental attitudes $[1,10]$.
According to the latest research, women find out about the possibility of midwife visit from their friends (who have already had such a consultation), from the Internet (mainly forums) or from the midwife herself who can provide such services. Fryc underlies that there is a huge need to educate patients as well as medical environment on the subject of midwives' competences that are widely described in many legislative documents. Doctors, nurses or physiotherapists knowing the range of services provided by primary health care midwives would more often refer women directly to them to be taken care of in various moments of their lives [11].

Recently, expenses on services provided by family midwives have increased, however, it was not related to the improvement of quality and quantity of provided services since more and more services related to midwife care are provided in private sector. National Health Fund pays primary health care midwives a capitation rate for "being ready to provide services" and for services paid extra, e.g. for educational advice among women before labor. Although the rate for pre-labor education is the highest, its percent is slim - results of the control of 2009 conducted by the Supreme Chamber of Control in Poland present that only $12.5 \%$ of expenses was pre-labor education provided by primary health care midwives and in 2010 it was only $15.7 \%$, what indicates that changes in financing services of family midwives are needed [12].

Presented results indicate the necessity of promoting the range of services provided by primary health care midwives among society as well as representatives of other medical professions so that they could correctly benefit from services provided by midwives.

\section{CONCLUSIONS}

1. Women receiving health services do not have sufficient knowledge regarding their doctor, midwife and nurse in primary health care.

2. There is a strong belief among women that midwives (including primary health care midwives) only take care of pregnant women and women after labor, however, they do not know that midwives also provide education related to prevention of gynecological diseases.

3. In reference to the low level of knowledge among society on the subject of competences of primary health care midwife, it is necessary to conduct actions that aim at promoting the profession of midwife and educating society in this field. 


\section{Wiedza kobiet korzystających ze świadczeń zdrowotnych na temat zadań położnej pracującej w podstawowej opiece zdrowotnej}

\section{WPROWADZENIE}

Profesja położnej istnieje od setek lat i dotyczy wszystkich warstw społeczeństwa, bez względu na pochodzenie, wiek czy epokę. Najczęściej towarzyszyła ona kobiecie w czasie porodu, doradzała w pierwszych dniach życia jej dziecka, ale także dzieliła się swoją wiedzą na temat naturalnych metod radzenia sobie $\mathrm{z}$ dolegliwościami miejsc intymnych. Akuszerki czy babki, jak je kiedyś nazywano, wspomagały kobiety w wielu momentach ich życia, co nadal funkcjonuje w środowiskach szpitalnych, ambulatoryjnych i domowych. Położna jest postrzegana przez społeczeństwo jako osoba potrzebna oraz użyteczna, gdyż czynności przez nią świadczone korelują z ludzkimi potrzebami $[1,2]$.

Pozycja zawodu położnej została uporządkowana w ustawie z dnia 15 lipca 2011 roku o zawodach pielęgniarki i położnej, gdzie uznana została jako osoba świadcząca usługi zdrowotne po uzyskaniu niezbędnych kwalifikacji [3]. Obecnie położna może pełnić różne funkcje w systemie ochrony zdrowia, w tym wchodzić w skład zespołu podstawowej opieki zdrowotnej (POZ) wraz z lekarzem oraz pielęgniarką $[3,4,5]$.

Zgodnie z ustawą z 27 października 2017 roku o podstawowej opiece zdrowotnej, położna podstawowej opieki zdrowotnej (in. położna rodzinna) to położna, która pracuje w placówce medycznej, posiadającej podpisaną umową z Narodowym Funduszem Zdrowia (NFZ) o świadczenie usług medycznych/zdrowotnych, lub samodzielnie ją zawarła $\mathrm{z}$ NFZ oraz spełnia jeden $\mathrm{z}$ poniższych kryteriów: posiada tytuł zawodowy magistra położnictwa; posiada tytuł specjalisty lub odbywa szkolenie specjalizacyjne w dziedzinie pielęgniarstwa rodzinnego; ukończyła lub odbywa kurs kwalifikacyjny w dziedzinie pielęgniarstwa rodzinnego; posiada tytuł specjalisty w dziedzinie pielęgniarstwa: środowiskowego, środowiskowo-rodzinnego oraz promocji zdrowia i edukacji zdrowotnej albo ukończyła kurs kwalifikacyjny w dziedzinie pielęgniarstwa: środowiskowego, środowiskowo-rodzinnego oraz promocji zdrowia i edukacji zdrowotnej $[4,6]$.

Pacjenci posiadający ubezpieczenie zdrowotne $\mathrm{w}$ Polsce, tj. świadczeniobiorcy, mają prawo do wybrania poszczególnych członków zespołu podstawowej opieki zdrowotnej - lekarza, pielęgniarki i położnej (dla chłopców do 2. miesiąca życia oraz kobiet od narodzin do starości). Wyboru takiego dokonuje się za pomocą tzw. „deklaracji wyboru”, czyli oświadczenia woli złożonego na piśmie w wybranej placówce medycznej $[4,6]$.

Kobiety w Polsce mają możliwość skorzystania z wielu świadczeń zdrowotnych, jakich udzielać może położna, w tym położna rodzinna. W świadomości społeczeństwa położna przede wszystkim jest utożsamiana z przyjmowaniem porodu oraz wizytami patronażowymi (poporodowymi), rzadziej z czynnościami niezwiązanymi z okresem ciąży. Jednakże zakres wykonywanych przez położne usług medycznych jest znacznie szerszy [1].

Według prawa obowiązującego w Polsce, położna ma prawo do sprawowania opieki nad kobietą w ciąży o fizjologicznym przebiegu czy interpretacji jej wyników badań [3]. Podobne unormowania prawne ustalono w innych państwach europejskich, m.in. w Anglii oraz Francji [8]. Jednakże w przypadku wyłącznej opieki nad ciężarną przez położną, musi ona skierować kobietę na konsultację do lekarza specjalisty (w dziedzinie położnictwa i ginekologii) 3 razy w ciągu ciąży oraz na badania ultrasonograficzne zgodnie $\mathrm{z}$ aktualnym standardem postępowania medycznego. Natomiast do położnej rodzinnej ciężarna powinna zostać skierowana przez lekarza prowadzącego w okresie pomiędzy 21. a 26. tygodniem ciąży [3] Położna podstawowej opieki zdrowotnej, oprócz rozpoznania i prowadzenia fizjologicznej ciąży, zajmuje się również pielęgnacją noworodka od pierwszych sekund życia, poradnictwem laktacyjnym dla młodych matek czy oceną prawidłowego rozwoju nowonarodzonego dziecka. Może ona udzielać fachowych porad dotyczących planowania rodziny, przebiegu ciąży (np. dieta, aktywność fizyczna, sposoby łagodzenia dolegliwości związanych z ciążą) i porodu (m.in. pozycje porodowe, metody relaksacji), profilaktyki kobiecych chorób nowotworowych lub chorób przenoszonych drogą płciową (np. HIV) [3]. Powyższe usługi są finansowane przez NFZ oraz odpowiednio rozliczane w zależności od przeprowadzonej usługi [6].

\section{CEL PRACY}

Celem pracy była próba określenia stanu wiedzy kobiet korzystających ze świadczeń zdrowotnych na temat zadań położnej w systemie podstawowej opieki zdrowotnej.

\section{MATERIAŁ I METODYKA}

Badania zostały przeprowadzone online w okresie od lutego do marca 2018 roku wśród kobiet mieszkających w Polsce, korzystających ze świadczeń zdrowotnych w podstawowej opiece zdrowotnej. W badaniu wzięło udział 200 respondentek w wieku 18-60 lat, które zostały poinformowane o dobrowolności, anonimowości udziału w badaniach, jak i wykorzystaniu uzyskanych wyników wyłącznie do celów naukowych. Do badań wykorzystano metodę sondażu diagnostycznego $\mathrm{z}$ wykorzystaniem autorskiego kwestionariusza ankiety, opracowanego na podstawie literatury przedmiotu. 
Uzyskane wyniki badań poddano analizie statystycznej. Bazę danych i badania statystyczne przeprowadzono w oparciu o oprogramowanie komputerowe STATISTICA 13.3 (StatSoft, Polska). Wartości analizowanych parametrów niemierzalnych przedstawiono przy pomocy liczności i odsetka. Dla niepowiązanych cech jakościowych do wykrycia istnienia różnic między porównywanymi grupami użyto testu jednorodności Chi2. Przyjęto poziom istotności $\mathrm{p}<0.05$.

\section{WYNIKI BADAŃ}

Większość ankietowanych kobiet mieszkała w mieście $(80,0 \%)$, posiadała wykształcenie wyższe $(77,0 \%)$, ponad połowa była w związku małżeńskim $(52,5 \%)$ i posiadała dzieci (52,5\%).

Wśród ankietowanych większość korzystała ze świadczeń podstawowej opieki zdrowotnej $(95,50 \%)$, w tym: $72,5 \%$ kilka razy w roku, $11,0 \%$ raz w miesiącu, 2,0\% więcej niż raz w miesiącu, natomiast $14,5 \%$ nie korzystało $\mathrm{z}$ powyższych usług $\mathrm{w}$ ciągu ostatniego roku (por. rycina 1).
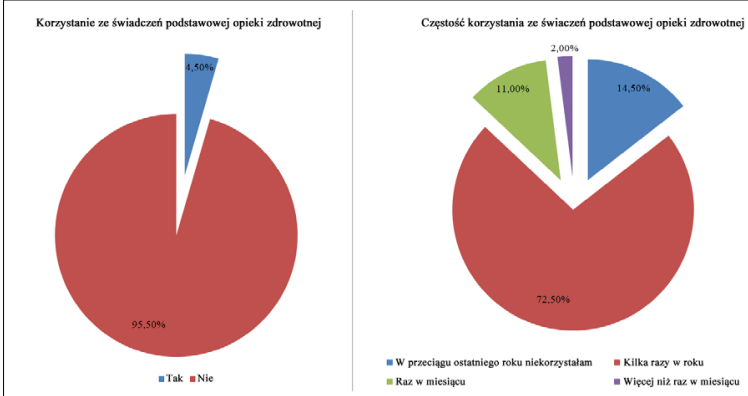

Ryc 1. Korzystanie ze świadczeń podstawowej opieki zdrowotnej przez respondentki

Tab. 1. Znajomość poszzzególnych członków zespołu podstawowej opieki zdrowotnej

\begin{tabular}{|c|c|c|c|c|c|c|c|}
\hline \multirow{2}{*}{$\begin{array}{l}\text { Znajomość } \\
\text { Zespołu P0Z }\end{array}$} & \multicolumn{2}{|c|}{ Lekarz P0Z } & \multicolumn{2}{|c|}{$\begin{array}{c}\text { Pielęgniarka } \\
\text { POZ }\end{array}$} & \multicolumn{2}{|c|}{ Położna P0Z } & \multirow{2}{*}{$\begin{array}{c}\text { Analiza } \\
\text { statystyczna }\end{array}$} \\
\hline & $\mathrm{N}$ & $\%$ & $N$ & $\%$ & $N$ & $\%$ & \\
\hline Tak & 175 & 87,5 & 82 & 41,0 & 100 & 50,00 & \multirow{3}{*}{$\begin{aligned} \mathrm{Chi}^{2} & =0,00075 \\
\mathrm{p} & =0,05\end{aligned}$} \\
\hline Nie & 15 & 7,5 & 86 & 43,0 & 66 & 33,00 & \\
\hline $\begin{array}{l}\text { Nie wiem, } \\
\text { czy posiadam }\end{array}$ & 10 & 5,0 & 32 & 16,0 & 34 & 17,00 & \\
\hline
\end{tabular}

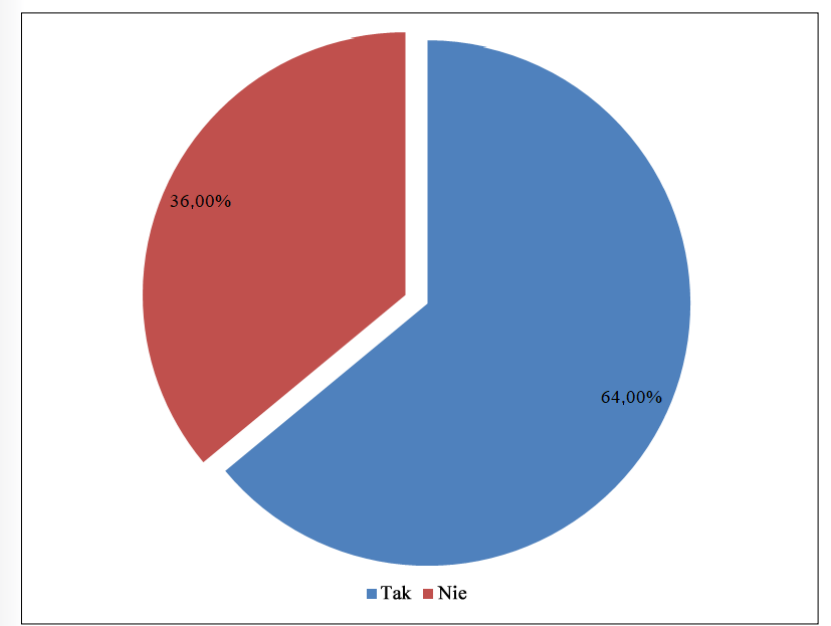

Ryc 2. Wiedza respondentek na temat posiadania zdeklarowanej położnej $\mathrm{POZ}$
Z przeprowadzonej analizy wynika, iż respondentki istotnie częściej znały swojego lekarza podstawowej opieki zdrowotnej (87,5\%) niż pielęgniarkę i położną $\mathrm{POZ}$ $(\mathrm{p}=0,05)$ (por. tabela 1$)$.

Znaczna część respondentek potwierdziła, iż każda kobieta powinna posiadać zadeklarowaną położną podstawowej opieki zdrowotnej (64,0\%) (por. rycina 2).

Zdecydowana większość ankietowanych wskazała, że położna sprawuje opiekę nad kobietą po urodzeniu dziecka $(88,0 \%)$ oraz nad noworodkiem $(84,0 \%)$, ma możliwość prowadzenia ciąży w przebiegu fizjologicznym $(71,0 \%)$ oraz prowadzi edukację na temat profilaktyki chorób kobiecych $(63,0 \%)$ (por. tabela 2).

\section{- Tab. 2. Wiedza respondentek na temat zadań położnej rodzinnej}

\begin{tabular}{|l|c|c|}
\hline Zadania położnej w podstawowej opiece zdrowotnej & N & $\%$ \\
\hline Sprawuje opiekę nad kobietą po urodzeniu dziecka & 176 & 88,0 \\
\hline $\begin{array}{l}\text { Prowadzi opiekę nad noworodkiem po powrocie ze szpitala } \\
\text { do 2. miesiąca życia }\end{array}$ & 168 & 84,0 \\
\hline $\begin{array}{l}\text { Sprawuje opiekę nad kobietą w ciąży fizjologicznej (tj. bez } \\
\text { powikłań) od poczęcia do porodu }\end{array}$ & 142 & 71,0 \\
\hline Prowadzi edukację na temat profilaktyki chorób kobiecych & 126 & 63,0 \\
\hline $\begin{array}{l}\text { Sprawuje opiekę nad kobietą po operacjach / zabiegach } \\
\text { ginekologicznych }\end{array}$ & 112 & 56,0 \\
\hline $\begin{array}{l}\text { Podaje leki różnymi drogami oraz technikami (zgodnie z } \\
\text { zaleceniami lekarza) }\end{array}$ & 95 & 47,5 \\
\hline $\begin{array}{l}\text { Udziela pierwszej pomocy w stanach zagrożenia życia lub w } \\
\text { przypadku porodu nagłego (w tym zagrożonego) }\end{array}$ & 95 & 47,5 \\
\hline Jest asystentką w badaniach wykonywanych przez lekarza & 92 & 46,0 \\
\hline $\begin{array}{l}\text { Wypisuje recepty na leki bądź wyroby medyczne (z pewnymi } \\
\text { wyjątkami) }\end{array}$ & 67 & 33,5 \\
\hline Nie wiem & 7 & 3,50 \\
\hline
\end{tabular}

*wyniki nie sumują się do 100\%, bo istniała możliwość zaznaczenia kilku odpowiedzi

Zgodnie ze standardami postępowania położna rodzinna przeprowadza przynajmniej 4 wizyty patronażowe u kobiety po porodzie. Wśród 51,43\% respondentek położne przeprowadziły wymaganą ilość wizyt - w tym $29,52 \%$ miało od 4 do 5 wizyt, a 21,90\% miało 6 wizyt patronażowych lub więcej. Niestety u $44,76 \%$ ankietowanych przeprowadzono mniejszą liczbę wizyt lub nie przeprowadzono ich w ogóle $(23,81 \%)$ (por. rycina 3$)$.

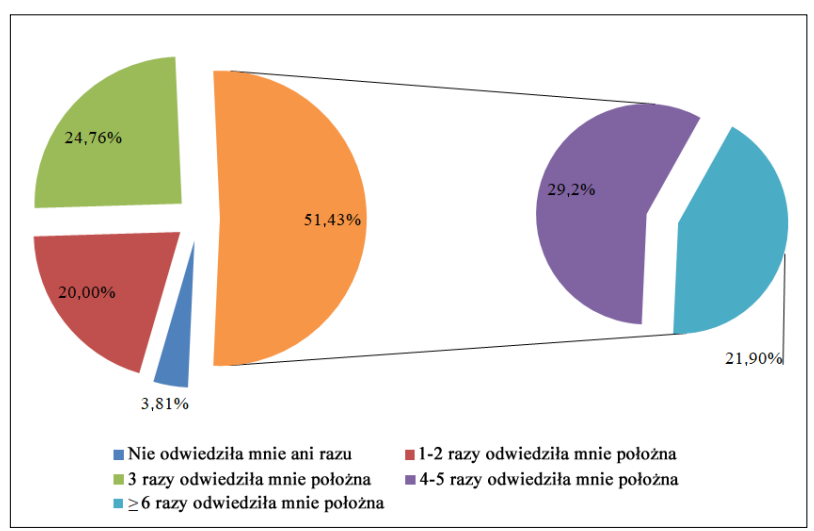

Ryc 3. Liczba odbytych wizyt patronażowych przez położną podstawowej opieki zdrowotnej według respondentek, które urodziły dziecko 
Ponad połowa badanych kobiet odpowiedziała, iż położna $\mathrm{POZ}$ sprawuje opiekę nad kobietami (od urodzenia do okresu starości) oraz chłopcami do 2. miesiąca życia (58,5\%). Jednak niemal jedna trzecia badanych uważała, że położna rodzinna zajmuje się tylko kobietami w okresie ciąży oraz porodu (29,0\%), a nieliczne są zdania, że tylko dziećmi do 2 . miesiąca życia (4,5\%). Natomiast $8,0 \%$ ankietowanych kobiet nie wiedziało w ogóle, do kogo są skierowane świadczenia położnej podstawowej opieki zdrowotnej (por. rycina 4).

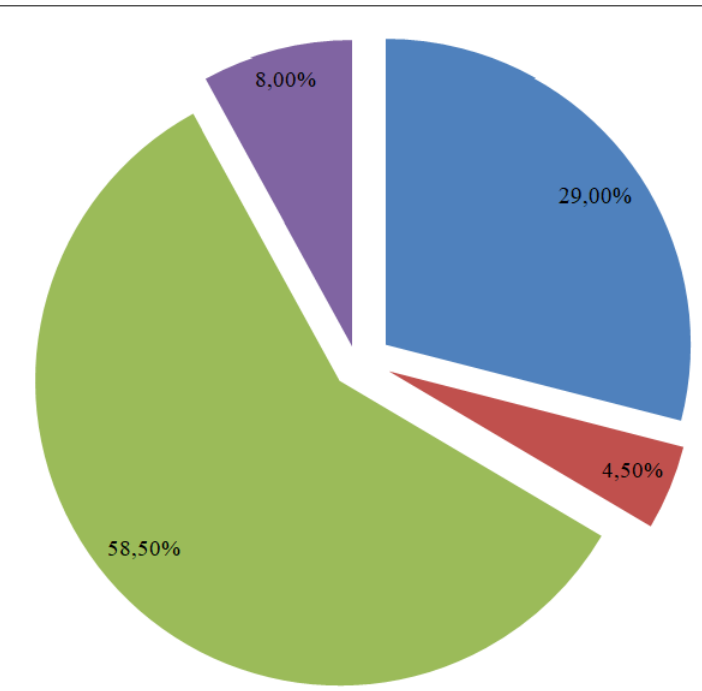

- Tylko kobietami w okresie ciąży i po porodzie

- Tylko dziećmi do 2 miesiąca życia (bez względu na płeć)

- Kobietami (od urodzenia do okresu starości)

oraz chłopcami do 2 miesiąca życia

- Nie wiem

Ryc 4. Grupa pacjentów, jaką zajmuję się położna podstawowej opieki zdrowotnej, według ankietowanych kobiet

Na pytanie dotyczące możliwości umówienia się na wizytę edukacyjną z położną rodzinną, ponad dwie trzecie ankietowanych zgodnie odpowiedziało, iż wszystkie kobiety mają taką możliwość (72,0\%), natomiast co piąta badana nie znała odpowiedzi na to pytanie $(20,5 \%)$ (por. rycina 5).

Ankietowane kobiety, na pytanie dotyczące zakresu porad edukacyjnych przeprowadzanych przez położną podstawowej opieki zdrowotnej, najczęściej odpowiadały, iż obejmują one tematykę związaną z przygotowaniem do porodu, $\mathrm{z}$ uwzględnieniem porodu rodzinnego (92,0\%), pielęgnacją i żywieniem dziecka do drugiego miesiąca życia $(84,0 \%)$, poradnictwem laktacyjnym oraz promowaniem karmienia piersią $(83,5 \%)$ (por. tabela 3 ).

$\mathrm{Z}$ analizy przeprowadzonego sondażu wynika, iż zdaniem respondentek położna POZ w głównej mierze monitoruje przebieg połogu, rozwoju noworodka i niemowlęcia do drugiego miesiąca życia $(86,0 \%)$ oraz wykonuje pomiary u kobiety, noworodka i dokonuje ich oceny $(82,0 \%)$, natomiast $\mathrm{w}$ mniejszym stopniu zajmuje się ona wystawianiem skierowań na wykonanie określonych badań diagnostycznych (44,5\%) (por. tabela 4).

Większość badanych kobiet odpowiedziało, iż usługi medyczne świadczone przez położne podstawowej opieki zdrowotnej są bezpłatne (69,5\%), zaś pozostała część

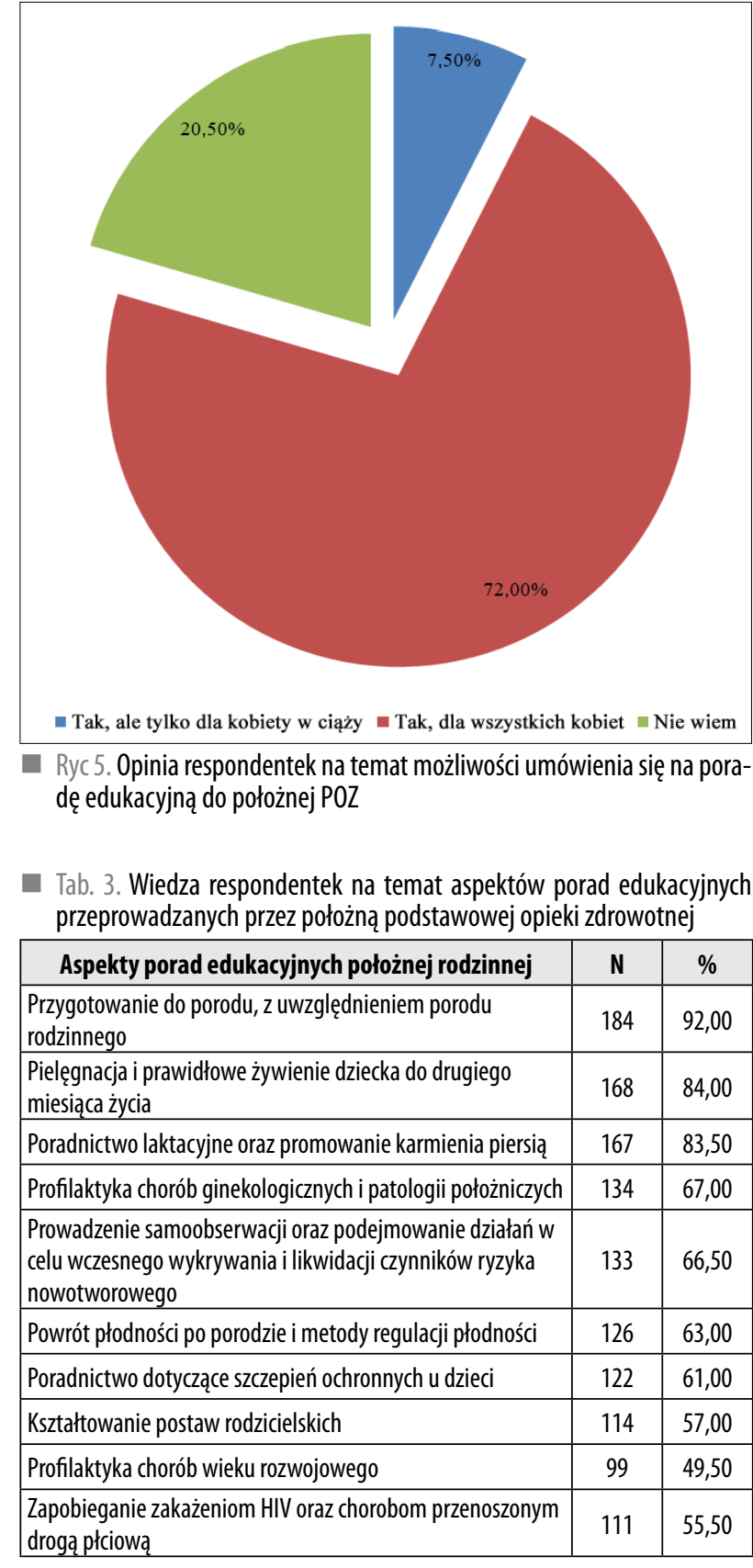

*wyniki nie sumują się do 100\%, bo istniała możliwość zaznaczenia kilku odpowiedzi

- Tab. 4. Wiedza badanych kobiet na temat świadczeń wykonywanych przez położną podstawowej opieki zdrowotnej

\begin{tabular}{|l|c|c|}
\hline \multicolumn{1}{|l|}{ Wykonywanie świadczeń medycznych przez położną } & N & $\%$ \\
\hline $\begin{array}{l}\text { Monitorowanie przebiegu połogu i rozwoju noworodka } \\
\text { i niemowlęcia do drugiego miesiąca życia }\end{array}$ & 172 & 86,00 \\
\hline $\begin{array}{l}\text { Wykonywanie pomiarów u kobiety i noworodka } \\
\text { oraz dokonywanie oceny tych pomiarów }\end{array}$ & 164 & 82,00 \\
\hline $\begin{array}{l}\text { Prowadzenie gimnastyki oddechowej, relaksacyjnej } \\
\text { i przygotowującej do porodu oraz połogu }\end{array}$ & 153 & 76,50 \\
\hline Przyjmowanie porodu nagłego w warunkach domowych & 146 & 73,00 \\
\hline $\begin{array}{l}\text { Prowadzenie ćwiczeń usprawniających w ciąży, połogu } \\
\text { i schorzeniach ginekologicznych }\end{array}$ & 144 & 72,00 \\
\hline Prowadzenie i monitorowanie rozwoju ciąży fizjologicznej & 134 & 67,00 \\
\hline Pobieranie materiału do badań diagnostycznych & 126 & 63,00 \\
\hline $\begin{array}{l}\text { Wykonywanie badania położniczego/ginekologicznego } \\
\text { u kobiet }\end{array}$ & 123 & 61,50 \\
\hline $\begin{array}{l}\text { Wystawianie skierowań na wykonanie określonych badań } \\
\text { diagnostycznych }\end{array}$ & 89 & 44,50 \\
\hline
\end{tabular}

*wyniki nie sumują się do 100\%, bo istniała możliwość zaznaczenia kilku odpowiedzi 
badanych uważała, iż powyższe świadczenia są płatne $(3,5 \%)$ lub nie miała zdania w tym zakresie $(27,0 \%)$ (por. rycina 6).

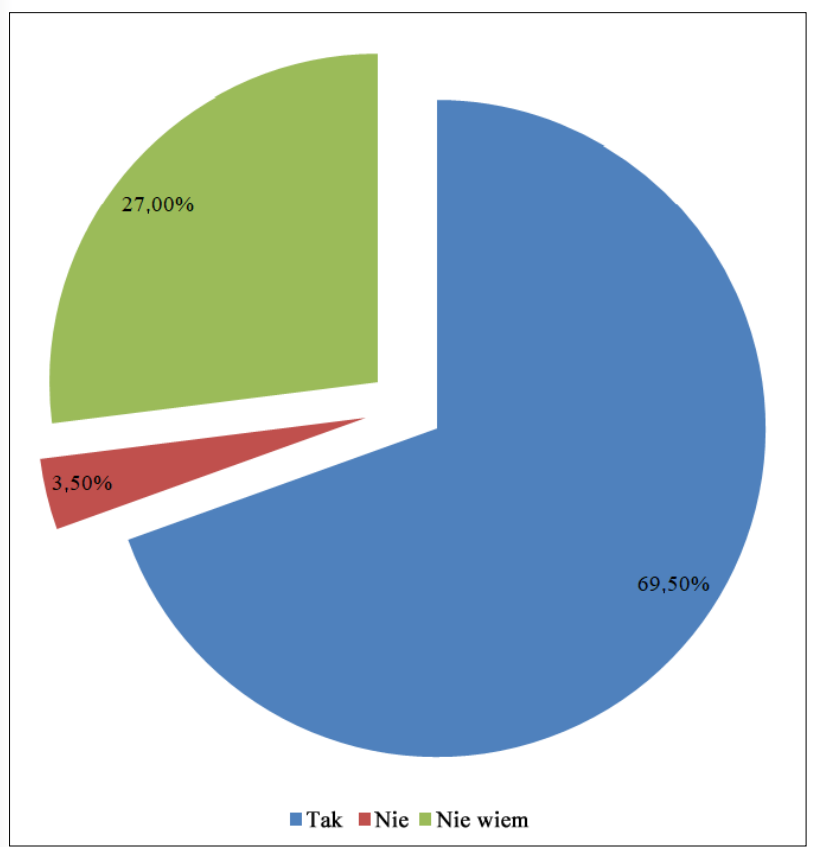

Ryc 6. Wiedza ankietowanych na temat płatności za usługi świadczone przez położną podstawowej opieki zdrowotnej

Ponad połowa ankietowanych na pytanie dotyczące znaczenia zawodu położnej rodzinnej odpowiedziała, iż jest ona niezbędną osobą w zespole podstawowej opieki zdrowotnej $(79,5 \%)$, natomiast pozostałe kobiety nie miały zdania w tej kwestii $(15,0 \%)$ lub uważały, iż położna nie jest potrzebnym członkiem zespołu POZ (5,5\%) (por. rycina 7$)$.

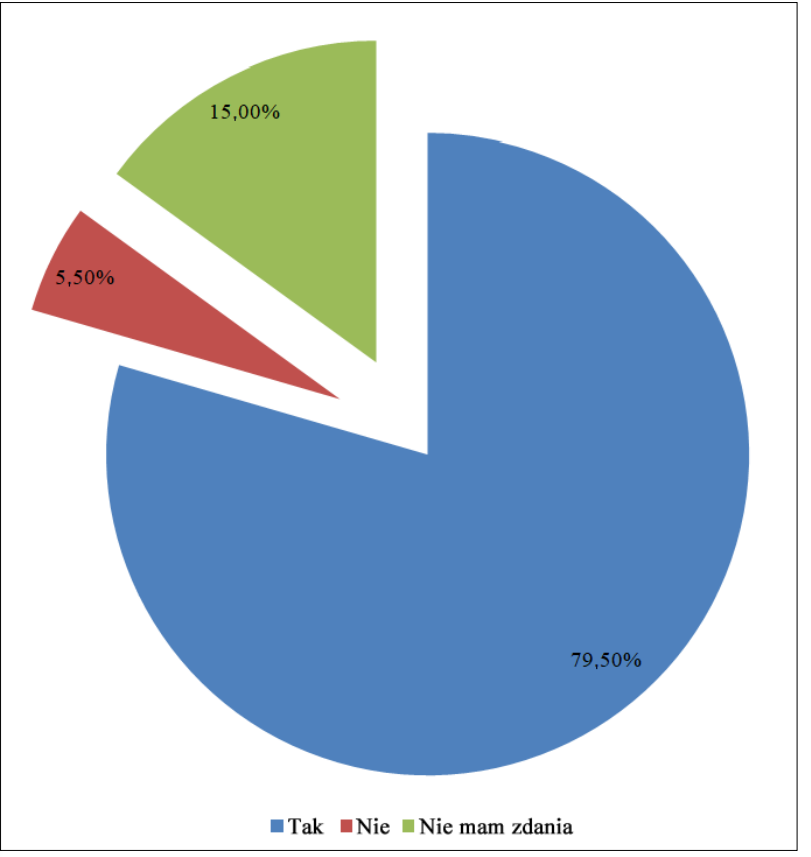

Ryc 7. Opinia respondentek na temat znaczenia osoby położnej w zespole podstawowej opiece zdrowotnej

\section{DYSKUSJA}

Dzięki uwarunkowaniom prawnym, jakie obowiązują w Polsce, położna posiada szerokie kompetencje zawodowe. Zdobyta wiedza oraz umiejętności umożliwiają jej samodzielne udzielanie różnych świadczeń zdrowotnych w środowisku szpitalnym lub ambulatoryjnym [3].

Podczas przeprowadzania powyższych badań uzyskano przydatne informacje na temat wiedzy kobiet korzystających ze świadczeń zdrowotnych, które dotyczą usług medycznych udzielanych przez położne podstawowej opieki zdrowotnej. W opinii ankietowanych położna rodzinna m.in. może sprawować opiekę nad kobietą w ciąży fizjologicznej (67\%) oraz nadzorować okres połogu (86\%). Potwierdzają to także doniesienia części autorów, które odnoszą się do aktów prawnych umożliwiających sprawowanie opieki przez położną w tym okresie, jednakże w badaniach z przełomu 2015/2016 roku wykazano, iż ponad połowa respondentek (61\%) nie wiedziała, że położna może być osobą prowadzącą ciążę $[1,9]$.

Wyniki badań własnych wskazują, że główną grupą odbiorców usług świadczonych przez położne rodzinne według ankietowanych były kobiety w okresie poporodowym oraz noworodki do 2. miesiąca życia, co również wykazano w badaniach z 1999 roku oraz 2011 roku. Natomiast we wszystkich analizach w opinii respondentek w mniejszym stopniu położna opiekuje się pacjentkami po zabiegach ginekologicznych oraz udziela porad związanych $\mathrm{z}$ kształtowaniem postaw rodzicielskich $[1,10]$.

Zgodnie z najnowszymi badaniami kobiety uzyskują wiedzę na temat możliwości odbycia wizyty u położnej głównie od swoich koleżanek (które odbyły już taką poradę), z Internetu (m.in. forum dyskusyjne) lub od samej położnej, mogącej udzielić takich świadczeń. Fryc podkreśla, że istnieje duża konieczność edukowania pacjentów, ale także środowiska medycznego na temat kompetencji położnych, szeroko opisywanych w wielu dokumentach ustawodawczych. Lekarze, pielęgniarki czy fizjoterapeuci, znając zakres usług świadczonych przez położne POZ, znacznie częściej kierowaliby kobiety bezpośrednio pod ich opiekę, wspomagając pacjentki w różnych momentach ich życia [11].

W ostatnich latach wydatki na świadczenia położnych rodzinnych wzrosły, jednak nie było to związane z poprawą jakości i ilości świadczonych usług, gdyż coraz więcej zadań związanych z opieką położnej realizowana jest w sektorze prywatnym. NFZ płaci położnych POZ stawkę kapitacyjną za "gotowość do udzielania świadczeń” oraz za świadczenia dodatkowo płatne, np. za porady edukacyjne u kobiet przed porodem. Mimo, iż za edukację przedporodową jest najwyższa stawka, to ich odsetek jest znikomy - w wynikach kontroli Najwyższej Izby Kontroli w Polsce w 2009 roku tylko 12,5\% wydatków stanowiła edukacja przedporodowa przeprowadzona przez położne POZ, a w 2010 roku tylko 15,7\%, co wskazuje na potrzebę zmian w sposobie finansowania świadczeń położnych rodzinnych [12].

Przedstawione wyniki wskazują na konieczność promowania zakresu zadań świadczonych przez położne podstawowej opieki zdrowotnej wśród społeczeństwa, 
jak i przedstawicieli innych zawodów medycznych, by prawidłowo mogli oni korzystać ze świadczeń udzielanych przez położne.

\section{WNIOSKI}

1. Kobiety korzystające ze świadczeń zdrowotnych mają niepełną wiedzę na temat tego, kto jest ich lekarzem, położną i pielęgniarką w podstawowej opiece zdrowotnej.

2. W świadomości kobiet istnieje przekonanie, że położne (w tym położne podstawowej opieki zdrowotnej) zajmują się wyłącznie kobietami w ciąży i po porodzie, natomiast nie wiedzą, iż położne zajmują się także edukacją dotyczącą profilaktyki chorób ginekologicznych.

3. W nawiązaniu do niskiego poziomu wiedzy społeczeństwa na temat kompetencji położnej podstawowej opieki zdrowotnej konieczne jest prowadzenie działań mających na celu promowanie zawodu położnej i uświadamianie społeczeństwa w tym zakresie.

\section{PIŚMIENNICTWO/REFERENCES}

1. Iwanowicz-Palus G, Golonka E, Bień A, Stadnicka G. Postrzeganie zawodu położnej przez społeczeństwo (Perception of midwife's profession by socjety). Pielęg. XXI w. 2013; 2(43): 35-42.

2. Iwanowicz-Palus G, Krysa J, Bień A. Rola położnej rodzinnej w Polsce. Med. Og. Nauk o Zdr. 2013; 19 (3): 272-278.

3. Ustawa z dnia 15 lipca 2011 r. 0 zawodach pielęgniarki i położnej (Dz.U. $2011 \mathrm{Nr} 174$ poz. 1039)

4. Ustawa z dnia 27 października 2017 r. o podstawowej opiece zdrowotnej (Dz.U. 2017 poz. 2217)

5. Biskupska M, Niewiadomski TJ. Współpraca położnych podstawowej opieki zdrowotnej z podmiotami świadczącymi opiekę nad kobietami, noworodkami i niemowlętami do drugiego miesiąca życia (Cooperation of primary health care midwives with institutions taking care of women during their life span, newborns and neonates less than two months old). Probl. Pielęg. 2009; 17 (4): 301-305.

6. Ustawa z dnia 27 sierpnia 2004 r. o świadczeniach opieki zdrowotnej finansowanych ze środków publicznych (Dz.U. $2004 \mathrm{nr} 210$ poz. 2135)

7. Obwieszczenie Ministra Zdrowia z dnia 7 lipca 2016 r. w sprawie ogłoszenia jednolitego tekstu rozporządzenia Ministra Zdrowia w sprawie standardów postępowania medycznego przy udzielaniu świadczeń zdrowotnych z zakresu opieki okołoporodowej sprawowanej nad kobietą w okresie fizjologicznej ciąży, fizjologicznego porodu, połogu oraz opieki nad noworodkiem (Dz.U. 2016 poz. 1132)

8. Iwanowicz-Palus G, Bień A, Rzońca E, Mazurek M. The scope of a midwife's competence in Poland and Great Britain - a comparative analysis. J. Publ. Health Nurs. Med. Rescue. 2016; 3: 27-31.

9. Leja-Szpak A, Bulanda K, Jaworek J. Opinia ciężarnych na temat kompetencji położnych w aspekcie prowadzenia ciąży fizjologicznej. Pielęg. Pol. 2018; 67 (1): 97-105.

10. Gałęziowska E. Rola położnej środowiskowej w przygotowaniu do porodu i opieki nad małym dzieckiem - opinie kobiet ciężarnych ze środowiska wiejskiego. [w:] Iwanowicz-Palus G. red. Położnictwo u progu XXI wieku. Materiały z Konferencji Naukowej, Lublin 19-20 marca 1999 r. Lublin, 1999: 233-238.

11. Fryc D. Zapotrzebowanie kobiet z województwa zachodniopomorskiego na usługi okołoporodowe świadczone przez położne oraz stopień znajomości przez środowisko medyczne ustawowych kompetencji zawodowych polskich położnych. Ann. Acad. Med. Stetin. 2014; 60 (2): 95-103.

12. Informacja 0 wynikach kontroli realizacji zadań położnych środowiskowych w zakresie podstawowej opieki zdrowotnej (Nr ewid.. 49/2011/P10144/LKR). Kraków 2011 [https://www.nik.gov.pl/plik/id,3004,vp,3795.pdf] dostęp: 27.08.2018.

Praca zgłoszona do czasopisma/Manuscript received: 31.05.2018

Praca zaakceptowana do druku/Manuscript accepted: 28.08.2018

Tłumaczenie/Translation: Monika Washington 